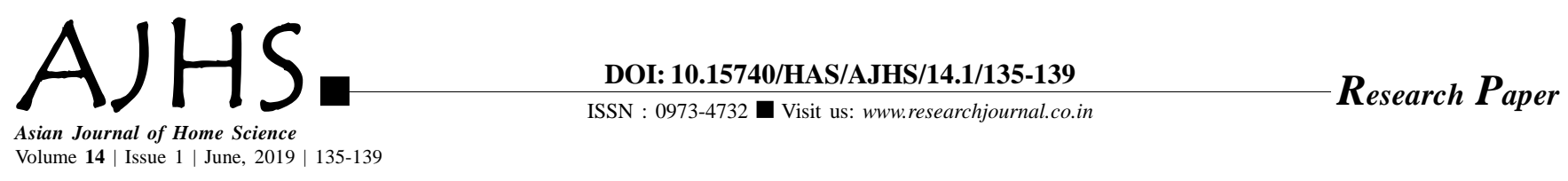

\title{
A study to analyze the women employment generated through Mahatama Gandhi National Rural Employment Gurantee Scheme in Anand district, Gujarat state
}

\author{
Komal Patel and Nidhi Gupta
}

Received: 18.03.2019; Revised: 29.04.2019; Accepted: 08.05.2019

See end of the paper for authors' affiliations

\section{Komal Patel}

Block Co-ordinator, Integrated Child Development Services, Borsad, Anand (Gujarat) India Email: komalvpate126@gmail. com

\begin{abstract}
DBSTRACT : The Mahatma Gandhi National Rural Employment Guarantee Act (here after referred to as MGNREGA or Scheme), enacted by the Central Government of India in September 2005 , provides a legal guarantee of one hundred days of employment per year in unskilled works to each rural household. Although livelihood security for rural households is its main objective, it also envisages the creation and maintenance of rural infrastructure, with a significant focus on agriculture (GOI, 2005). The scheme was initially implemented in February 2006 in the poorest 200districts, termed the 'Phase 1' districts; it was extended to another 130 'Phase 2'districts in April 2007 and in April 2008 it was implemented in the remaining 'Phase 3' districts as well. Women in Indian society represent a totally deprived lot. Their empowerment has a great potential in leading the country to spectacular development. The emerging issues and challenges in rural India also compel us to adopt a pragmatic support system to empower the women. MGNREGA (Mahatma Gandhi National Rural Employment Guarantee Act) and its implementation support this agenda through facilitating the essential processes of entrepreneurship, capacity building, education, health and hygiene etc. especially by involving the women folk of the rural India. The achievement of inclusive growth and overall development is highly dependent on the gender equality and prosperity of women in the rural society. The present paper has made an attempt to study the participation of women through MNREGA in various states of India and also in districts of Anand. The highest employment status amongst women in terms of person days can be seen in Kerela. When we consider the total employment status of Anand district through MNREGA, a total of 62, 213 person days employment is generated, out of which the share of women stands at 48.10 per cent. The highest employment status amongst women in terms of person days can be seen in Anand district with 69.98 per cent.
\end{abstract}

KEY WORDS: Empowerment, Women empowerment, MGNREGA

- HOW TO CITE THIS PAPER : Patel, Komal and Gupta, Nidhi (2019). A study to analyze the women employment generated through Mahatama Gandhi National Rural Employment Gurantee Scheme in Anand district, Gujarat state. Asian J. Home Sci., 14 (1) : 135-139, DOI: 10.15740/HAS/AJHS/14.1/135-139. Copyright@ 2019: Hind Agri-Horticultural Society. 